\title{
Environmental perception of gatherers of the crab 'caranguejo-uçá' (Ucides cordatus, Decapoda, Brachyura) affecting their collection
} attitudes

\author{
Rômulo RN Alves*1, Alberto K Nishida² and Malva IM Hernández²
}

Address: ${ }^{1}$ Departamento de Biologia, Universidade Estadual da Paraíba and Programa de Pós-Graduação em Ciências Biológicas (Zoologia), Departamento de Sistemática e Ecologia, Universidade Federal da Paraíba, 58051-900 João Pessoa, PB, Brazil and ²Departamento de Sistemática e Ecologia, Universidade Federal da Paraíba, 58051-900 João Pessoa, PB, Brazil, PB, Brasil

Email: Rômulo RN Alves* - romulo_nobrega@yahoo.com.br; Alberto K Nishida - guy@dse.ufpb.br; Malva IM Hernández - malvamh@yahoo.com

* Corresponding author

Published: 03 November 2005

Journal of Ethnobiology and Ethnomedicine 2005, I:10 doi:10.1186/1746-4269-1-10

This article is available from: http://www.ethnobiomed.com/content/I/I/I0

(c) 2005 Alves et al; licensee BioMed Central Ltd.

This is an Open Access article distributed under the terms of the Creative Commons Attribution License (http://creativecommons.org/licenses/by/2.0), which permits unrestricted use, distribution, and reproduction in any medium, provided the original work is properly cited.

\section{Introduction}

Mangrove forests are productive ecosystems found along the coastal zones of Brazil, providing several profitable resources such as timber, medicinal products, natural dye, fish, crustaceans, and molluscs. For the littoral dwellers of Northeast Brazil, the Brachyura crabs are a major economic resource. The main species they commercialize are the 'goiamum' (Cardisoma guanhumi), 'siris' (Callinectes spp), and the land crab 'caranguejo-uçá' (Ucides cordatus). The land crab is the most exploited species, and of most relevance for people living in the surrounding mangrove areas in the State of Paraiba [1-3].

$U$. cordatus lives in an individual burrow ca. $1 \mathrm{~m}$ deep, situated under mangrove trees. Adult crabs have few predators, notably the crab-eating racoon (Procyon cancrivorous), monkeys, and hawks [4]. Despite this, a high predation pressure on $U$. cordatus is exerted by humans who harvest this species for food [5]. In the Northeast Region of Brazil, the exploitation of $U$. cordatus holds particular socio-economic importance since it involves many local residents, who benefit from both direct and indirect employment $[2,3]$. Crab gatherers have observed that the natural stock of $U$. cordatus has decreased alarmingly since 1998, when an unexpected crab mass-mortality event occurred in the mangrove habitats of the Paraiban littoral [3]. The subsequent low crab abundance created social problems in the surroundings of those mangrove areas and seriously
Received: 26 August 2005

Accepted: 03 November 2005 affected the economic welfare of poor people who depend upon crab gathering for their livelihoods.

The need for research on the exploitation of mangrove ecosystems and on $U$. cordatus in particular was emphasized by Maneschy [6], who also suggested the need to study the socio-economics of crab collecting, which has recently experienced an increase in production demand. The life of gatherers is intimately linked to ecological processes and cycles, and their daily involvement with the exploitation of other natural resources will likely help them to develop harvesting strategies for maximizing the crab catch efficiency. An understanding of the ecology of $U$. cordatus by local gatherers is an important component of the process of exploitation $[2,6]$.

In recent years, researchers have emphasized the importance of traditional knowledge amongst fishermen. They have also emphasized the potential role that traditional fishing practices can play in the development and implementation of sustainable fishery management in the modern world [7-9]. Human communities which rely directly on their natural resources for subsistence, often have a detailed understanding of their local environment [10-12]. The economic, social, and cultural activities of such people often depend upon local environmental goods and services [13]. 


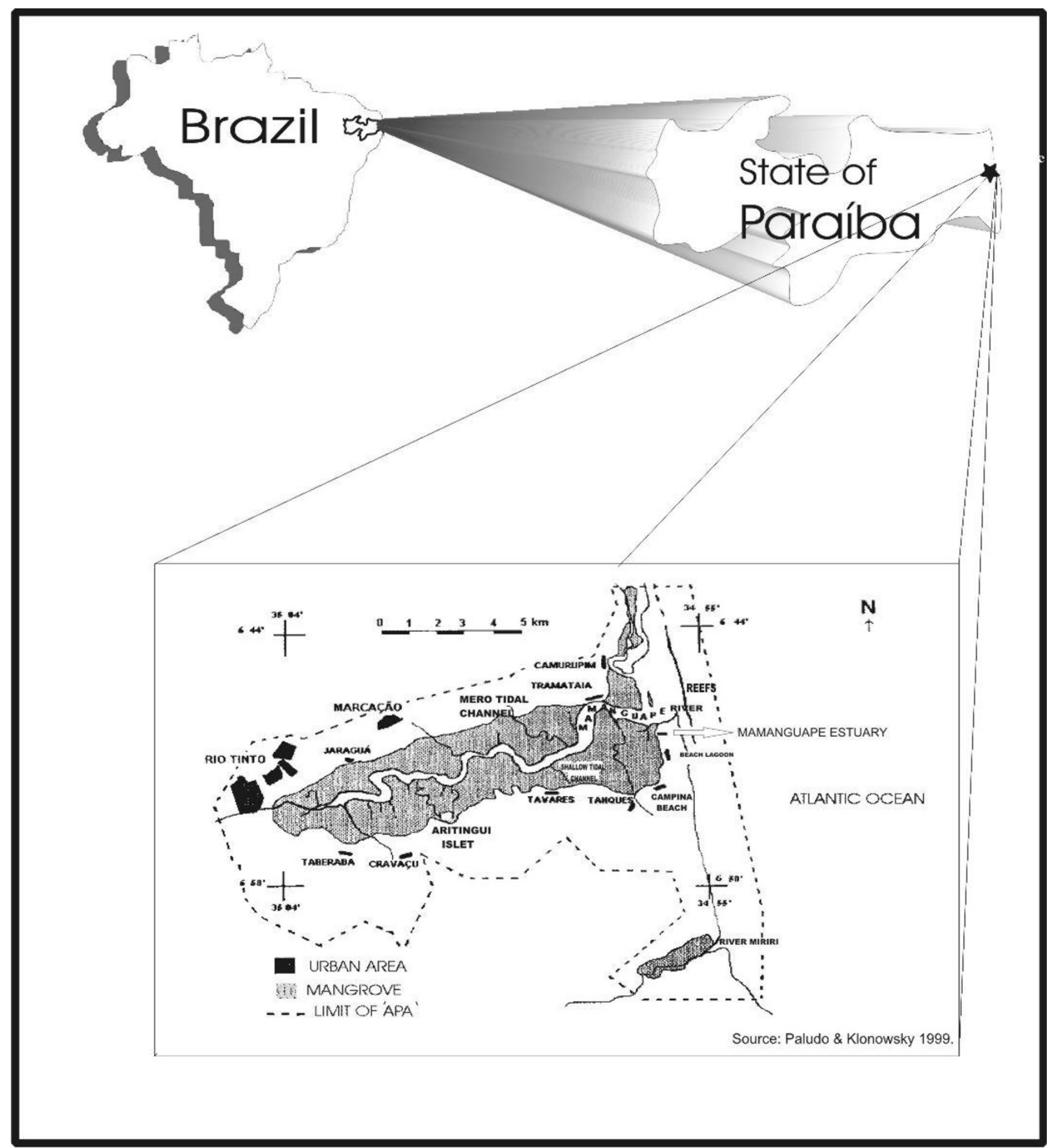

Figure I

Map showing the estuary of the River Mamanguape.

Ecologists and environmental managers have generally disregarded the possibilities of learning from the traditional human communities [14]. However, a recent acknowledgment of their relevance has led to an intensification of studies on traditional knowledge [14-18]. In Brazil alone, Diegues [19] listed 868 relevant publications on 


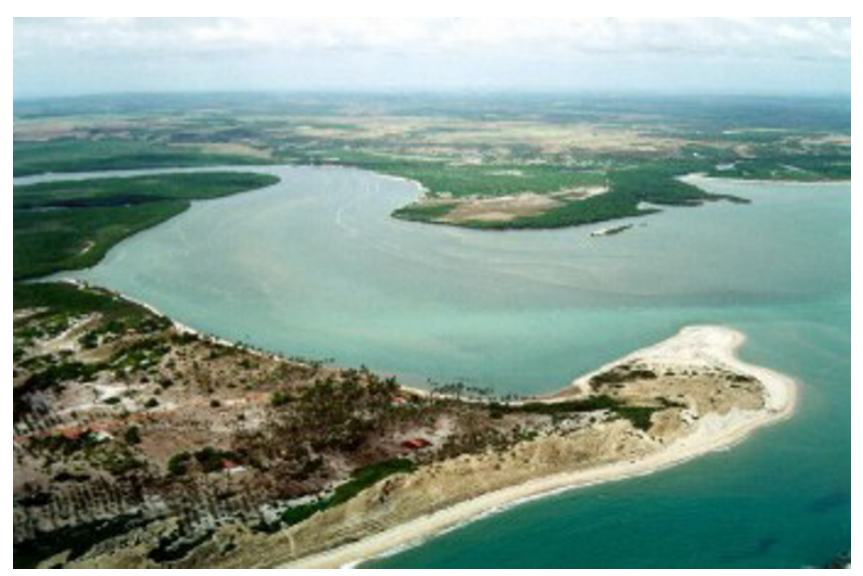

Figure 2

Aerial view of River Mamanguape estuary (Photo: João Carlos).

traditional human populations, of which nearly $80 \%$ were published over the last 20 years, and mainly in the last decade.

Traditional knowledge may help in the establishment of management plans aimed at the sustainable exploitation of natural resources [2,3]. Nordi [20] observed that the government environmental organization controlling the capture of $U$. cordatus does not consider local human knowledge of the ecology of the species, a fact that possibly explains the poor effectiveness of the regulations governing the exploitation of this resource. $U$. cordatus individuals are caught manually or by the use of some tools which allow easier access to them. In most of Brazilian States professional crab gatherers are male [21].

During normal harvest procedures gatherers select crabs with respect to both sex and size. In particular, male crabs are preferred due to their higher flesh yield [22]. Gatherers have developed the ability for distinguishing the sex of crabs as inferred from the track the animal leaves close to burrow openings, as well as from the size of burrow entrances. This perception is important since it directly influences the capture process since large male crabs are preferred due to their higher commercial value. The aim of the present work is to evaluate the ability of gatherers to discriminate the sex and size of crabs, and the importance of this ability on the development of successful harvest strategies. It is also intended here to evaluate the implications of this perception for establishing measures aimed at the conservation and management of $U$. cordatus.

\section{Methods}

\section{Study areas}

The research was carried out in the mangrove forests of the Mamanguape river, Northeast Brazil, located between lat
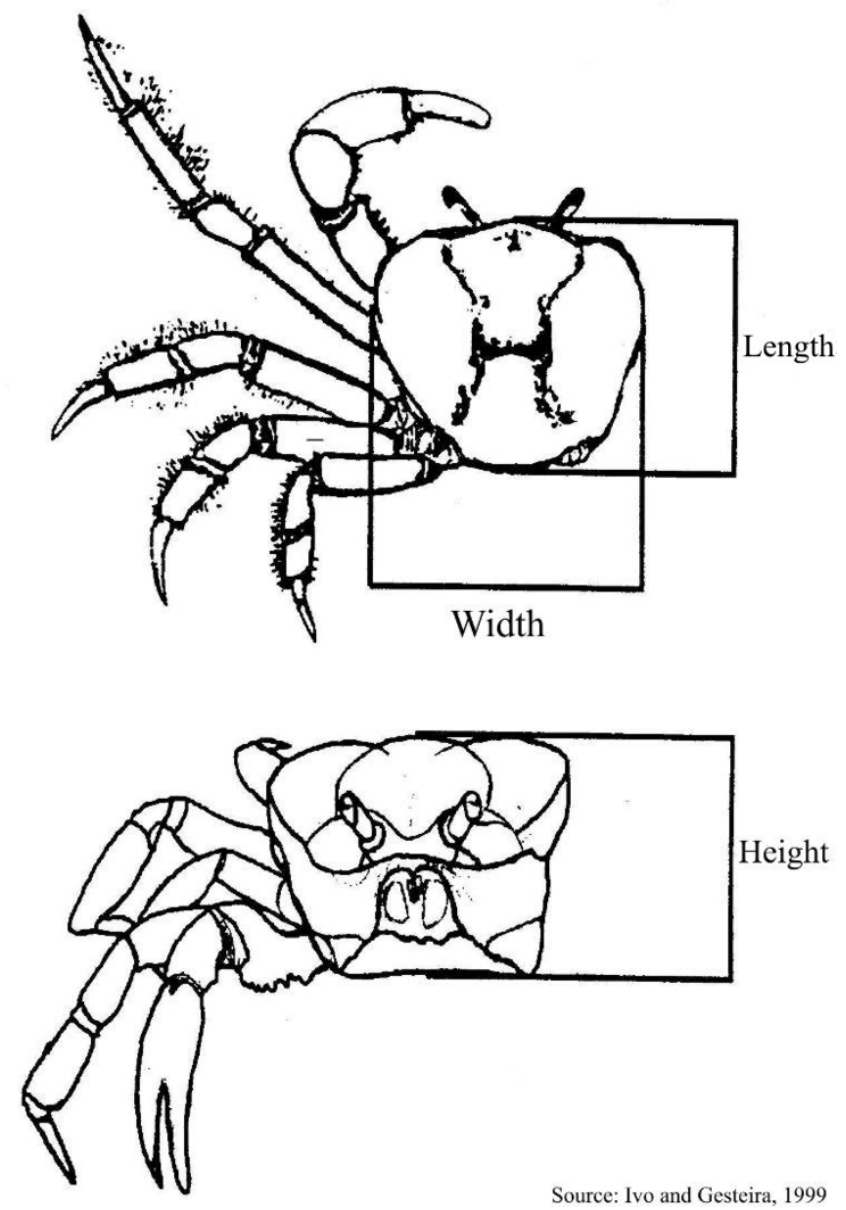

Figure 3

Morphometric measurements taken from the carapace of Ucides cordatus (Photo: Guy Nishida).

$06^{\circ} 43^{\prime}$ and $06^{\circ} 51^{\prime} \mathrm{S}$, and long $35^{\circ} 07^{\prime}$ and $34^{\circ} 54^{\prime} \mathrm{W}$. The estuary studied here, is nearly $24 \mathrm{~km}$ long from east to west, and $2.5 \mathrm{~km}$ wide nearest to the river mouth (Figs 1 and 2).

All the area of the influence of the Mamanguape river is within the permanent protected area (APA, in Portuguese) of 'Barra do Rio Mamanguape' of IBAMA (the Brazilian Institute for the Environment and Natural Resources), formed also by the estuaries of the rivers Miriri and Estivas, and covering a total of 14,460 ha. In that estuary there is a large extension of mangrove forest, islands, and islets (the latter formed by sandy-clay-loam banks), and barrier reefs in the rivers mouths together form an elongated sand bar. The whole area is located in the municipalities of Rio Tinto, Marcação, and Lucena, in the State of Paraíba (Figure 2).

The estuary of the APA includes $c a .6,000$ ha of a reasonably well preserved mangrove forest, the largest of its kind 
Table I: Pearson's correlation ( $r$ values) between the burrow opening dimensions and the Ucides cordatus carapace dimensions $(\mathrm{n}=$ 210 ; * significant at $\mathrm{p}<0.05)$.

\begin{tabular}{lccc}
\hline Burrow opening dimensions $(\mathrm{cm})$ & Carapace dimensions $(\mathrm{cm})$ & \\
\hline & Carapace height & Carapace length & Carapace width \\
Burrow opening height & $0.37^{*}$ & $0.58^{*}$ & $0.59^{*}$ \\
Burrow opening width & $0.40^{*}$ & $0.60^{*}$ & $0.62^{*}$ \\
\hline
\end{tabular}

in the State of Paraíba. The common trees are Rhizophora mangle, Avicennia germinans, A. schaueriana, Laguncularia racemosa and Conocarpus erectus. The tallest $R$. mangle trees reach $25 \mathrm{~m}$ and are up to $60 \mathrm{~cm}$ DBH (diameter at breast height); A. germinans trees are taller than $30 \mathrm{~m}$ and have up to $65 \mathrm{~cm}$ DBH [1].

Despite the fact that the Mamanguape mangrove forest is relatively well preserved, some sites appear to be affected by anthropogenic activities, mainly derived from sugar cane cultivation. Watanabe [23] reported water contamination in one of the estuary tributaries from sugar cane plantations. According to local fishermen, a decrease in fish production has been observed due to an increase in the amount of agrochemicals used in plantations along the river banks.

\section{Procedures}

The research was performed between November and October 2002. Before starting the field work, a meeting was held with crab gatherers to inform them about the goals of our study, and research methods, and to propose their participation in our investigations.

In order to respect indigenous intellectual property rights, we followed an informal research protocol: before the survey, we briefly explained the nature of the research and specific objectives to each interviewee [28]. We were precluded from adopting a formal approach using interview consent forms, owing to the poor level of organization among the community of gatherers, and high illiteracy rates $[2,3]$.

We selected ten gatherers typical of the community of gatherers, with each having at least 20 years of experience and being from the middle income range. The perception and discrimination ability of crab gatherers was analysed through direct observations, as a 'non-member participant observer' [24], complemented by open interviews and informal conversations [25-27]. Each gatherer was interviewed individually, there was no time limit for the interviews and they lasted between 1 and 3 hours each. We joined the gatherers (one at a time) in their daily activities. During the course of the study they captured 210 crabs. Morphological measurements were taken using venier callipers, accurate to $1 \mathrm{~mm}$. Crab carapaces were measured with respect to: (a) height, taken dorsoventrally from its central point; (b) length, taken from the sagittal plain on the dorsal surface of the animal; and (c) width, taken transversally from the first pair of pereiopods. The carapace width corresponds to the largest body dimension (Fig. 3). The burrow opening of each caught animal was simultaneously measured with respect to height (the longest axis) and to width (the shortest axis).

The gatherer was asked to guess the sex the animal he was going to catch. His perception was then evaluated after a careful examination of the crab external sexual characteristics, following Mota Alves [29]. The possible association between what gatherer expectation and observed sex classification was evaluated using a chi-square test in a $2 \times 2$ contingency table with Yates correction [30].

\section{Results}

The carapaces length ranged from $3.2 \mathrm{~cm}$ to $5.8 \mathrm{~cm}$, with a mean of $4.27 \mathrm{~cm}( \pm 0.424)$; the width ranged from 4.1 $\mathrm{cm}$ to $6.7 \mathrm{~cm}$ with a mean of $5.53 \mathrm{~cm}( \pm 0.537)$; and the height ranged from $2.6 \mathrm{~cm}$ to $6.2 \mathrm{~cm}$ with a mean of 3.52 $\mathrm{cm}( \pm 0.480)$. The height of the burrow openings ranged from $3.4 \mathrm{~cm}$ to $7.3 \mathrm{~cm}$ with a mean of $5.72 \mathrm{~cm}( \pm 0.694)$, and the width ranged from $3.2 \mathrm{~cm}$ to $7.1 \mathrm{~cm}$ with a mean of $5.21 \mathrm{~cm}( \pm 0.693)$. The data for both carapace size and burrow entrance size were normally distributed.

The correlation analysis performed on the burrows opening dimensions and carapace dimensions showed positive and significant correlations $(\mathrm{p}<0.05)$ (Table 1$)$.

The variables with the most biological significance with respect to crab behaviour of going into and coming out of the burrows, are the width of the burrow opening and the crab carapace length. The regression analysis performed with these two variables generated the equation: burrow opening width $=1.02+0.98 \times$ crab length; and showed that each centimetre increase of the carapace length corresponds to $0.98 \mathrm{~cm}$ increase of the burrow opening width $(\mathrm{r}=0.60 ; \mathrm{p}<0.05)$.

The crab gatherers reported that they are able to distinguish male from female animals through the tracks their limbs leave on soil at the burrow entrance (Fig. 4). The females do not have virtually any hairs in their legs (Fig. 


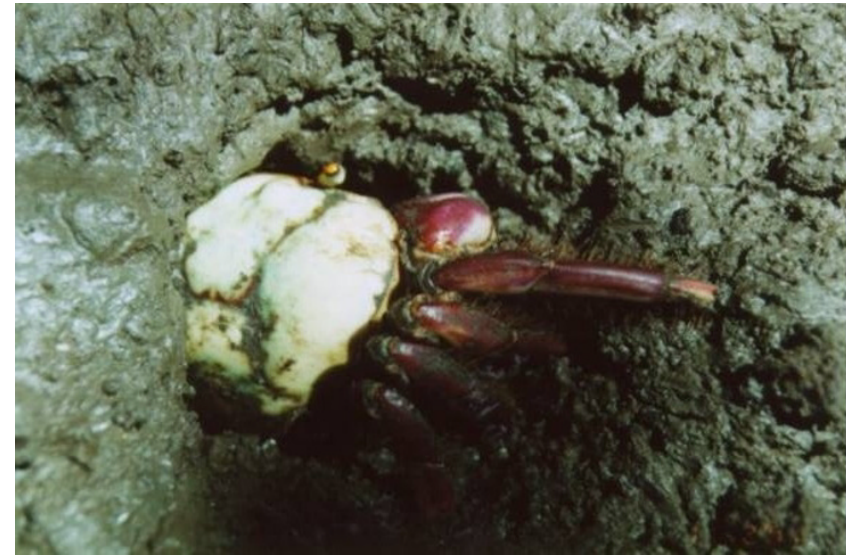

Figure 4

Ucides cordatus specimen entering the burrow (Photo: Guy Nishida).

5), and leave thin deep tracks at the burrow entrance, in opposition to the hairy legs of males (Fig. 6), leaving relatively wide and shallow tracks. Figure 7 shows a landcrab gatherer during harvesting activities.

The data obtained in this study showed a highly successful perception of crab sex amongst gatherers, i.e. $75.2 \%$ of the 210 individuals caught were successfully identified with respect to sex, of which $45.2 \%$ were males and 30\% were females (Table 2). The chi-square test showed a positive and highly significant association $\left(\chi^{2}=53.27 ; \mathrm{df}=1 ; \mathrm{p}<\right.$ 0.01 ) between the animal sex expected by the crab gatherer, and the sex recorded following examination of the animals. The $24.8 \%$ of mis-identifications comprised of $6.7 \%$ of the males and $18.1 \%$ of the females they caught. Consequently, mis-identifications are nearly three times more likely in the case of female individuals compared to males (Table 2).

\section{Discussion}

The proportionality between the crab's carapaces and the burrow openings had already been reported by other authors [31-33]. Their results were confirmed by this present study.

The correlation analysis showed that the crab morphometric values of length and width, as well as burrow opening dimensions were the main variables which had a significant association. The following conclusions can be reached from our results: carapace height was weakly correlated with burrow opening height $(\mathrm{r}=0.37)$ and with burrow opening width $(\mathrm{r}=0.40)$, probably because $U$. cordatus individuals enter the burrow by flexing their chelipeds frontally to the body, in a way that the longest axis of the burrow opening (its height) corresponds to the carapace height (Figure 3). This lateral movement of young

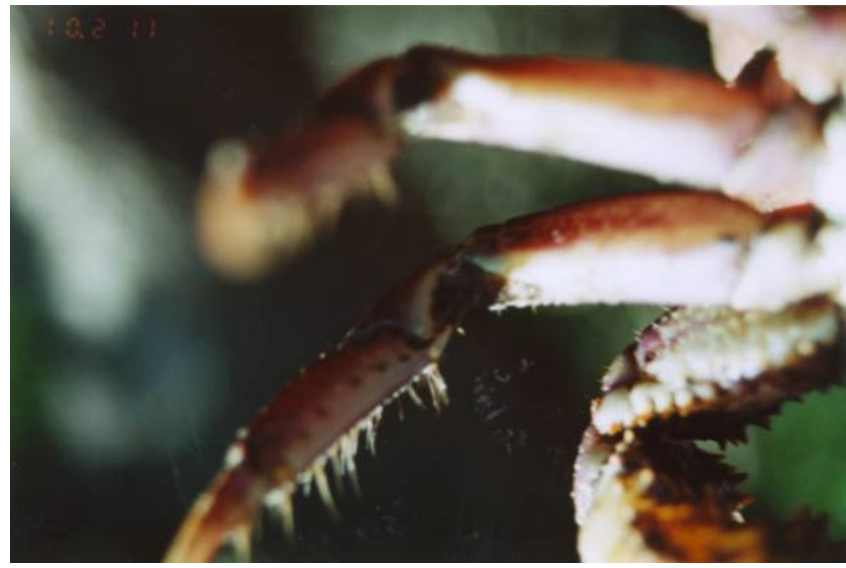

Figure 5

Legs of Ucides cordatus females virtually without hairs (Photo: Guy Nishida).

and adult male and female crabs was also observed by Costa [33]. Geraldes and Calventi [34] reported that the 'caranguejo-uçá' enters the burrow laterally, positioning first either the largest or the smallest claw. They also observed that the burrow opening was a little larger $(0.34$ $\mathrm{cm})$ than the crab carapace length.

The gatherers' observation that the larger the burrow the bigger the crab (as was confirmed by the present study), is important with regard to maximising the harvest obtained by the gatherers.

With respect to the gatherers perception of crab sex, Maneschy [6] also reported that in Pará State, North of Brazil, they distinguish the crabs' sex through their tracks left in front of the burrow openings, but that sometimes mistakes are made. According to crab gatherers of River Mamanguape area, some other factors affect their ability to successfully discriminate the sex of crabs, including the tide dynamics and sediment compaction. Areas washed away by high tides or with hardened sediments, are difficult places to recognize the crabs tracks. Gatherers are also aware of the sex and size of the crabs they target by direct observation of the burrow entrances. Therefore the catches are selective, since large male specimens have a higher commercial value.

Based on the catch selectivity of $U$. cordatus individuals, where both smaller sized and female individuals are not collected but returned to their habitat, Ivo and Gesteira [22] stated that this crustacean can be sustainably harvested. However, despite this conclusion, depletions of natural stocks of $U$. cordatus have been reported in the States of Paraíba [2,3], Espírito Santo [35], and Pará [36]. It is therefore important to consider several other factors, besides exploitation through human harvesting, that have 
Table 2: Percentage success of sex perception of Ucides cordatus crabs by local gatherers.

\begin{tabular}{ccccc}
\hline $\begin{array}{c}\text { Sex expected by the } \\
\text { gatherer }\end{array}$ & Sex observed & Gatherer hits (\%) & Gatherer misses (\%) \\
\cline { 2 - 4 } & Male & Female & & \\
\hline Male & $95(\mathrm{hit})$ & $38(\mathrm{miss})$ & 45.2 & 18.1 \\
Female & $14(\mathrm{miss})$ & $63(\mathrm{hit})$ & 30.0 & 6.7 \\
Total & $109(51.90 \%)$ & $101(48.10 \%)$ & 75.2 & 24.8 \\
\hline
\end{tabular}

contributed to reduce natural populations of $U$. cordatus, the most important of which is habitat degradation. In Brazil, like in many other tropical countries, mangrove forests have been widely cleared through anthropogenic activities

Another important factor is the precarious social conditions within which the crab gatherers' families survive $[2,3]$, a factor that is associated with the unpredictability of both the capture success of the animal and market demand, and often forces gatherers to harvest crabs in a non-selective approach [37]. All interviewees had a low income of about US\$ 100 per month (roughly equal to the minimal wage in Brazil). Crab gathering is the most important means of subsistence for the families of the crab gatherers, despite their supplemental income from small-scale agriculture activity, and the extraction of other natural resources. Crab gatherers are economically marginal groups, extremely poor and largely ignored by other artisanal fishermen. Despite this, the animals they capture are an important component of regional cuisine, as well as being sold commercially in urban centers.

The focus on crab harvesting as providing the economic foundation of these communities may lead them to an economic dependence on buyers, who are therefore in a position to exploit the gatherers. This would mask their perception about their harmful actions on the environment. In the case of common resources, a subject discussed by Burke [38], we agree that '... simply because resource users are not aware of the collective environmental costs of resource use does not make them irrational. It simply means their resource use follows a rationale other than the logic of the commons - possibly the logic of consuming more of a thing for which they have a preference'.

At the present time and despite prohibitions imposed by the government concerning the minimum size of crabs allowed to be caught, small sized and female specimens are also being collected. Therefore, the size-selective harvesting is practised only at sites where large crabs are abundant. This present situation may lead to an overexploitation of crab populations in mangrove forests of the State of Paraíba, especially at sites presently experienc- ing strong anthropocentric pressure. A similar situation has been observed in the mangrove ecosystems of the States of Rio de Janeiro and São Paulo, where U. cordatus is considered to be under risk of extinction $[39,40]$.

As observed by Bergallo [39] the decrease in the rate at which the individuals of some species can meet each other, is a clear sign of the reduction in population size. This observation corroborates the need to carry out conservation programs, especially considering that $U$. cordatus is a valuable economic resource. The strong (and perhaps unsustainable) predation pressure exerted on this species through human exploitation can be interpreted as a consequence of (1) the lack of an efficient environmental management policy, (2) the lack of studies and actions regulating the commercialization of its catch, and (3) the lack of alternative socio-economic proposals aimed at improving the welfare of local human communities directly involved with the exploitation of $U$. cordatus.

The implementation of a successful management strategy fundamentally requires the involvement of the main stakeholders, who must be made aware of the need for the conservation of the natural resource as a guarantee for its sustainable exploitation [41]. In this sense, the gatherers are critical stakeholders in the process of establishing management plans, which would ensure the sustainable exploitation of the resource. In Brazil, management of coastal fisheries is usually imposed on local communities by the federal government, without taking the either traditional knowledge or the reality of their socioeconomic conditions into consideration - with negative consequences for management plans.

The knowledge derived from traditional fishermen may contribute to strategic ecological managements [42], particularly in research areas with scarce or non-existent data $[43,44]$. Ethnoecological studies may also help in promoting dialogue and cooperation between fishers and scientists. The scientific literature illustrates the significance and value of traditional knowledge in Brazil. Alves and Nishida [2], for example, reported on the influence of tide variations on the ecdysis of the mangrove crab Ucides cordatus in natural environments, based on information 


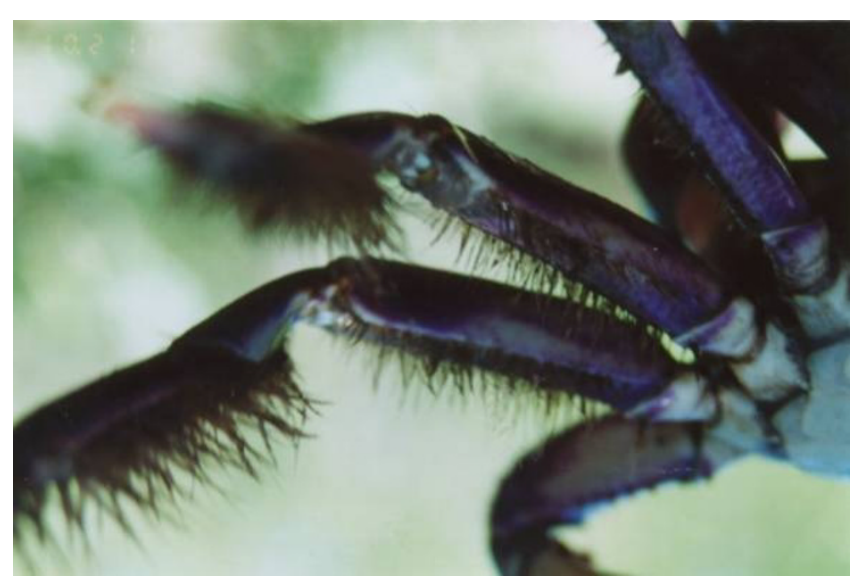

Figure 6

Hairy legs of Ucides cordatus males (Photo: Guy Nishida).

obtained from gatherers. Marques [45] also reported the gathering of relevant local information on the diet of an estuarine fish (Arius herzbergii, Ariidae).

Cultural values and perceptions arising from more experienced elder people need to be taken into account before any decision about their livelihoods can be considered by the relevant governmental authorities. Their contributions are essentially concerned with the sustainable management of local resource, and such contributions unfortunately have not yet been given satisfactory representation in the decision making process.

\section{Conclusion}

The results obtained here make evident that gatherers of Ucides cordatus have developed an intimate knowledge of the natural history of this species. Thus, they have developed skills that led them to become efficient harvesters. The unique nature of this local knowledge demonstrates the need for considering these factors in the implementation of management plans of coastal mangrove ecosystems. Gatherers' knowledge can provide a useful basis for understanding local crab stocks and their population dynamics. This kind of information may be used for establishing extractive reserves as well as for delimiting the harvest season and for establishing protected areas where animal species reproduce, aiming to maintain their natural stocks.

In the State of Paraíba the law prohibits that females of any size and males smaller than $4.5 \mathrm{~cm}$ of carapace length be captured. We believe that the re-examination of the existing laws of crab harvesting and other crustaceans are urgently needed for the preservation of natural stocks of these animals. The gatherer's environmental perception and its consequent influence on capture efficiency, are the main factors to be considered when making decisions

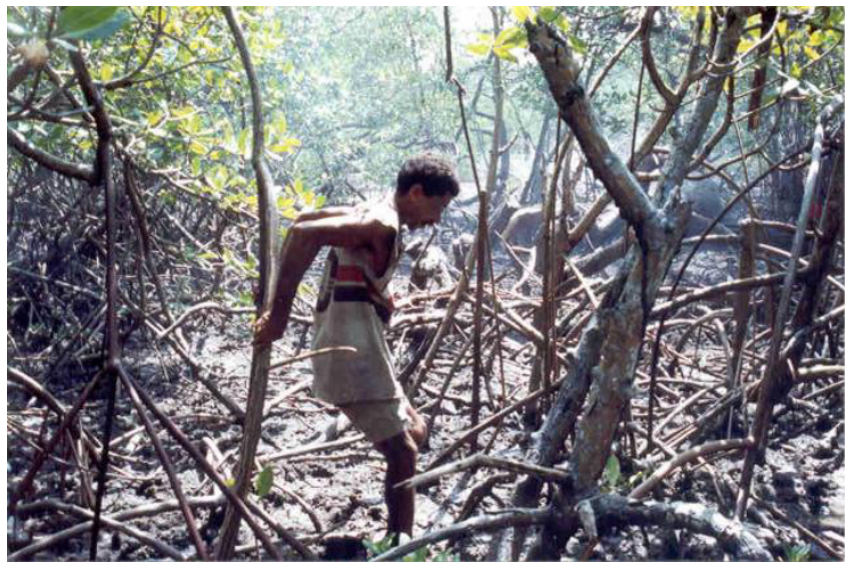

Figure 7

Gatherer of the land crab 'caranguejo uçá' (Ucides cordatus) in the mangrove habitat the River Mamanguape estuary.

about sustainable exploitation of mangrove ecosystems resources. Such decisions would only be effectively applied if the local knowledge held by crab gatherers as well as their socioeconomic conditions do not continue to be ignored by governmental authorities.

\section{Acknowledgements}

We are grateful for the cooperation of gatherers of 'caranguejo-uçá' in Paraiba State, since our research was founded on their knowledge. We are also grateful to CAPES (Coordenadoria de Aperfeiçoamento de Pessoal de Ensino Superior), WWF and USAID for financial supports, and to Dr Breno Grisi for translating this work into English and Toby Gardner for English comments and suggestions.

\section{References}

I. Palludo D, Klonowski VS: Barra de Mamanguape - PB: Estudo do impacto do uso de madeira de manguezal pela população extrativista e da possibilidade de reflorestamento e manejo dos recursos madeireiros. In Série Cadernos da Reserva da Biosfera Volume 16. Mata Atlântica, MAB, UNESCO; 1999:7-54.

2. Alves RRN, Nishida AK: A ecdise do caranguejo-uçá, Ucides cordatus (Crustacea, Decapoda, Brachyura) na visão dos caranguejeiros. Interciencia 2002, 27(3): | | 0 - I I7.

3. Alves RRN, Nishida AK: Aspectos socioeconômicos e formas de percepção ambiental dos catadores de caranguejo-uçá Ucides cordatus cordatus (L. I763) (Decapoda, Brachyura) do estuário do rio Mamanguape. Interciencia 2003, 28(I):36-43.

4. Koch V: Epibenthic production and energy flow in the Caeté mangrove estuary, North Brazil. In PhD thesis University of Bremen; 1999.

5. Diele K: Life history and population structure of the exploited mangrove crab Ucides cordatus (L.) (Decapoda: Brachyura) in the Caeté estuary. In Zentrum fur Marine tropenökologie Center for Tropical Marine Ecology. Bremen; 2000.

6. Maneschy MC: A mulher está se afastando da pesca? Continuidade e mudança do papel da mulher na manutenção doméstica entre famílias de pescadores no litoral do Pará. Boletim do Museu Paraense Emílio Goeldi, Antropologia 1995, I I (2): I 45 - 166.

7. Diegues AC: Sea tenure, traditional knowledge and managementamong brazilian artisanal fishermen NUPAUB. Universidade de São Paulo; 2002.

8. Ruddle K: Systems of knowledge: Dialogue, relationships and process. Environment, Development and Sustainability 2000, 2:277-304.

9. Cordell JC: Remaking the waters: the signficance of sea tenure-based protected areas. In Third Conference on Property rights, 
economics and environment International Center for research on Environmental issues, Aix-en-Provence, France; 2000.

10. Berlin B: Ethnobiological Classification. Principles of Categorization of Plants and Animals in Tradicional Societes Princeton University Press; 1992.

I I. Gadgil M, Berkes F, Folke C: Indigenous knowledge for biodiversity conservation. Ambio 1993, 22: I5I-I56.

12. Berkes F: Sacred Ecology - Traditional Ecological Knowledge and Resource Management Taylor \& Francis, Philadelphia; 1999.

13. Diegues AC: Os pescadores artesanais e a questão ambiental. Povos e Mares NUPAUB, São Paulo, Brasil; 1995.

14. Poizat $G$, Baran E: Fishermen's knowledge as background information in tropical fish ecology: a quantitative comparison with fish sampling results. Environmental Biology of fishes 1997, 50:435-449.

15. Johannes RE: Fishing and traditional knowledge. In Traditional Ecological Knowledge: a Collection of Essays Edited by: Johannes RE. IUCN, Gland; 1989:39-42.

16. Pajaro MG, Vincent ACJ: Seahorse conservation in Central Philippines: a community-based approach. Sea Wind 1996, I0(4):7-12.

17. Pajaro MG, Vincent ACJ, Buhat DY, Perante NC: The role of seahorse fishers in conservation and management. Proceedings of the Ist International Symposium in Marine Conservation Hong Kong 1997:1 18-126.

18. Skaptadóttir UD: Women coping with change in an iceland fishing community: a case study. Women's Studies International Forum 2000, 23(3):3| |-32|

19. Diegues CA, Arruda RSV, Silva VCF, Figols FAB, Andrade D: Biodiversidade e comunidades tradicionais no Brasil: Os saberes tradicionais e a Biodiversidade no Brasil NUPAUB-USP, PROBIO-MMA, CNPq, São Paulo; 1999.

20. Nordi N: A captura do caranguejo-uçá (Ucides cordatus) durante o evento reprodutivo da espécie: o ponto de vista dos caranguejeiros. Revista Nordestina de Biologia I994, 9(I):4 I-47.

21. Vergara Filho WL, Pereira Filho O: As mulheres do caranguejo. Ecologia e Desenvolvimento 1995, 5(53):34-36.

22. Ivo CTC, Gesteira TCV: Sinopse das observações sobre a bioecologia e pesca do caranguejo-uçá, Ucides cordatus cordatus (Linnaeus, I763), capturado em estuários de sua área de ocorrência no Brasil. Boletim Técnico Científico CEPENE 1999, 7(I):9-5I.

23. Watanabe T, Oliveira RB, Sassi R, Melo GN, Moura GF, Gadelha CL Machado VMN: Evidences of contamination caused by sugarcane monoculture and associated industrial activities in water bodies of the State of Paraíba, Northeast Brazil. Acto Limnologica Brasiliensia 1994, 5:85-101.

24. Sttebins RA: Fitting in: the researcher as learner and participant. Quality and Quantity 1987, 21:103-108.

25. Huntington HP: Using traditional ecological knowledge in science: methods and applications. Ecological Applications 2000, I 0: | $270-1274$.

26. Mello LG: Antropologia cultural. Editora Vozes, Rio de Janeiro 1995.

27. Chizzoti A: Pesquisa em ciências humanas e sociais Cortez editora, São Paulo; 2000.

28. Silvano R, Begossi A: Local knowledge on a cosmopolitan fish Ethnoecology of Pomatomus saltatrix (Pomatomidae) in Brazil and Australia. Fisheries Research 2005, 71:43-59.

29. Mota Alves MI: Sobre a reprodução do caranguejo-uçá, Ucides cordatus (Linnaeus), em mangues do Estado do Ceará (Brasil). Arquivos de Ciências do Mar 1975, I 5(2):85-91.

30. Zar JH: Biostatistical Analysis Prentice-Hall, Englewood Cliffs. NJ, USA; 1984.

31. Alcântara-Filho P: Contribuição ao estudo da biologia e ecologia do caranguejo-uçá, Ucides cordatus (L. I763) (Crustacea, Decapoda, Brachyura), no manguezal do rio Ceará (Brasil). Arquivos de Ciências do Mar 1978, I 8: |-41.

32. Blankensteyn A, Cunha Filho D, Freire AS: Distribuição, estoques pesqueiros e conteúdo protéico do caranguejo do mangue Ucides cordatus (L. I 763) (Brachyura Ocypodidae) nos manguezais da Baía das Laranjeiras e adjacências, Paraná, Brasil. Arquivos de Biologia e Tecnologia 1997, 40(2):331-349.

33. Costa RS: Fisioecologia do caranguejo-uçá, Ucides cordatus (Linnaeus, 1763) -Crustáceo, Decápode - do Nordeste brasileiro. In PhD Thesis, USP-University of São Paulo, São Paulo State, Brazil; 1972
34. Geraldes MG, Calventi IB: Estudios experimentales para el mantenimiento en cautiverio del cangrejo Ucides cordatus. Ciencia Interamericana 1983, 23(I-4):4l-53.

35. Nunes AGA: Os argonautas do mangue: uma etnografia visua dos caranguejeiros do Município de Vitória - ES. In MSc Dissertation UNICAMP-Campinas University, Campinas, São Paulo State, Brazil; 1998.

36. Gondim M, Araújo FB: Redução dos tamanhos dos caranguejos (Ucides cordatus L.) capturados nos manguezais de Maracanã, zona do Salgado Paraense [abstract]. Anais do $3^{\circ}$ Congresso de Ecologia do Brasil 1996:260.

37. Nordi N: Os catadores de caranguejo-uçá (Ucides cordatus) da região de Várzea Nova (PB): Uma abordagem ecológica e social. In PhD Thesis UFSCar-Federal University of São Carlos, São Carlos, São Paulo State, Brazil; 1992.

38. Burke BE: Hardin Revisited: A Critical Look at Perception and the Logic of the Commons. Human Ecology 29(4):449-476.

39. Bergallo HG, Rocha CFD, Van Sluys M, Alves MAS: A fauna ameaçada de extinção do Estado do Rio de Janeiro EdUERJ, Rio de Janeiro; 2000.

40. Governo do Estado de São Paulo: Fauna ameaçada no Estado de São Paulo Série PROBIO/SP. Secretaria do Meio Ambiente; 1998.

41. Rodrigues AMT, Branco EJ, Saccardo AS, Blankensteyn A: A explotação do caranguejo Ucides cordatus (Decapoda: Ocypodidae) e o processo de gestão participativa para normatização da atividade na região Sudeste- Sul do Brasil. Boletim do Instituto de Pesca 2000, 26(I):63-78.

42. Seixas C, Begossi A: Ethnozoology of caiçaras from Aventureiro, Ilha Grande. Journal of Ethnobiology 200 I, 2 I (I): I07-I 35.

43. Ruddle K: A Guide to the Literature on Traditional Community-Based Fishery Management in the Asia-Pacific Tropics Rome: FAO Fisheries Circular Number 869, FIPP/C869; 1994

44. Johannes RE: The case for data-less marine resource management: examples from tropical nearshore finfisheries. Trend in Ecology and Evolution 1998, I 3:243-246.

45. Marques JGW: Aspectos ecológicos na etnoictiologia dos pescadores do complexo estuarino-lagunar de Mundaú-Manguaba, Alagoas. In PhD Thesis Universidade Estadual de Campinas, São Paulo; 1991. 